\title{
Dissolved carbon fixation by sponge-microbe consortia of deep water coral mounds in the northeastern Atlantic Ocean
}

\author{
Fleur C. van Duyl*, Jan Hegeman, Astrid Hoogstraten, Conny Maier
}

Royal Netherlands Institute for Sea Research, PO Box 59, 1790AB Den Burg, Texel, Netherlands

\begin{abstract}
We studied dissolved organic and inorganic carbon fixation in 2 sponge species from deep water coral mounds, viz. the demosponge Higginsia thielei and the hexactinellid sponge Rossella nodastrella. Sponges were collected between 500 and $700 \mathrm{~m}$ depth on coral mounds in the Rockall Trough (NE Atlantic). Prokaryote densities in sponge associations were on average $2.0 \times 10^{8}$ $\mathrm{cm}^{-3}$ in $H$. thielei and $2.5 \times 10^{8} \mathrm{~cm}^{-3}$ in $R$. nodastrella (ca. 7 to $30 \%$ Archaea, 36 to $65 \%$ Bacteria, counted after DAPI staining). Sponge samples were incubated in ultra-filtered seawater with ${ }^{3} \mathrm{H}-$ leucine and ${ }^{14} \mathrm{C}$-bicarbonate. Mean leucine-based carbon production was $4 \mathrm{nmol} \mathrm{C} \mathrm{cm}{ }^{-3}$ sponge $\mathrm{d}^{-1}$ for $H$. thielei and 2 to $4 \mathrm{nmol} \mathrm{C} \mathrm{cm}^{-3} \mathrm{~d}^{-1}$ for $R$. nodastrella. Average bicarbonate fixation by box-cored H. thielei was $0.7 \mathrm{nmol} \mathrm{C} \mathrm{cm}{ }^{-3}$ sponge d $\mathrm{d}^{-1}$ and up to $4.5 \mathrm{nmol} \mathrm{C} \mathrm{cm}^{-3} \mathrm{~d}^{-1}$ by $R$. nodastrella. Bicarbonate fixation by sponges was enhanced by $\left(\mathrm{NH}_{4}\right)_{2} \mathrm{SO}_{4}$ addition to the incubations. Net ammonia oxidation and nitrite production were established for both sponge species and indicated the presence of sponge-associated nitrifiers. Results suggest that sponge-associated chemoautotrophic/mixotrophic nitrifying prokaryotes may contribute to the observed $\mathrm{CO}_{2}$ assimilation. On average, dissolved carbon was processed 100 to 150 times faster by sponge-microbe consortia of $H$. thielei and $R$. nodastrella than by planktonic microbes in ambient water. Preliminary estimates suggest that the assimilation of dissolved (in)organic carbon contributed up to $10 \%$ of total carbon assimilation by sponge-microbe consortia of $H$. thielei and $R$. nodastrella.
\end{abstract}

KEY WORDS: Deep water coral reef - Sponge-associated prokaryotes $\cdot$ Leucine incorporation · Bicarbonate fixation · Nitrification

Resale or republication not permitted without written consent of the publisher

\section{INTRODUCTION}

Sponges are well represented on cold water coral mounds (Reitner \& Hoffmann 2003, Van Soest et al. 2007a), which are most common in the dark ocean between 400 and $1000 \mathrm{~m}$ depth (Roberts et al. 2006). Coral mound distribution is restricted by temperature (maximum $13^{\circ} \mathrm{C}$ ) and hard substrata for settlement (Rogers 1999). Cold water coral reefs in the North East Atlantic are built primarily by the branching stony corals Lophelia pertusa and Madrepora oculata, which provide hard substrata with diverse spatial complexity (e.g. rubble pavement to more complex 3-dimensional structures) harboring a large variety of benthic organ- isms. The density, diversity and cover of benthic suspension and filter-feeding organisms are especially remarkable on cold water coral reefs (e.g. Jensen \& Frederiksen 1992, Roberts et al 2006); this assemblage is often dominated by sponges (Van Soest et al. 2007).

The food sources that support deep water coral communities are not well understood. Hydrocarbon seeps are thought to provide food (Hovland \& Thomsen 1997), but, at least for the NE Atlantic, there are no indications that hydrocarbon seeps contribute to the food requirements of cold water coral communities (Masson et al. 2003). It is more likely that the system is fuelled mainly by particulate and dissolved organic matter derived from the euphotic zone (Frederiksen et 
al. 1992, Duineveld et al. 2004, Hopkinson \& Vallino 2005). At times, relatively 'fresh' particles characterized by labile lipids such as polyunsaturated fatty acids reach the sea floor (Kiriakoulakis et al. 2004). These particles release labile dissolved organic matter (DOM) that is consumed mainly by prokaryotes. However, prokaryote abundance and productivity in the deep sea are usually low (e.g. Herndl et al. 2005); hence prokaryotes may be an inadequate year-round food energy source for sponges (which feed predominantly on prokaryotes, e.g. Pile et al. 1996, Yahel et al. 2007) in cold water coral reef habitats. Alternatively, DOM in ambient seawater may also be used directly as a nutrition source by benthic organisms, as reported for shallow water tropical coral reefs (De Goeij \& Van Duyl 2007).

More than $40 \%$ of the biomass of marine sponges may consist of prokaryotes (e.g. Vacelet \& Donadey 1977, Wilkinson 1978a,b). Sponge-associated prokaryotes are thought to mediate dissolved organic carbon (DOC) removal by the sponge, and they can be a source of nutrition for the sponge cells in oligotrophic environments (e.g. Reiswig 1981). Substantial DOM removal by the tropical demosponges has been reported only recently (Yahel et al. 2003, De Goeij et al. 2008). Moreover, rapid proline uptake by sponge-associated prokaryotes and subsequent transfer of proline to sponge cells suggests a trophic link between DOM, symbionts and host (Wilkinson \& Garrone 1979). Whatever the pathway might be, DOM consumption by sponge-microbe consortia would allow the sponges to survive in areas with low levels of particulate organic carbon (e.g. dark ocean). Whether DOM is a source of carbon for sponges living on cold water coral reefs is as yet unknown and has been addressed in this study.

Inorganic carbon fixation has not yet been established for sponges living in the dark ocean, but it is considered likely in the light of recent findings of chemoautotrophy at these depths (Lam et al. 2004, Herndl et al. 2005, Ingalls et al. 2006). The dominance of Crenarcheota below $100 \mathrm{~m}$ depth in the NE Atlantic (op. cit.) and their capacity to fix bicarbonate (Wuchter et al. 2003, Hallam et al. 2006) by ammonia oxidation (Könneke et al. 2005) opens up new pathways in the ocean carbon cycle. Many sponge species harbor a high diversity of Bacteria and Archaea (Taylor et al. 2007). Nitrification by sponges and the presence of ammonia and nitrite oxidizing prokaryotes (chemoautotrophs) in sponges (e.g. Diaz \& Ward 1997, Hentschel et al. 2002, Jiménez \& Ribes 2007) is likely coincident with bicarbonate fixation.

We hypothesized that DOM and dissolved inorganic carbon (DIC) are incorporated as a supplementary nutrient source in deep water coral reef sponges of the dark oligotrophic ocean. We determined the abun- dance of sponge-associated prokaryotes and tested the ability of sponge-microbe consortia of the demosponge Higginsia thielei and the hexactinellid sponge Rossella nodastrella to assimilate leucine at nanomolar concentrations for protein synthesis and to fix DIC in the dark. Additional experiments were conducted to detect nitrification by chemolithoautotrophic/mixotrophic prokaryotes associated with these sponges. Carbon fixation rates of DOC and DIC in the sponges were compared with $\mathrm{C}$-fixation rates in the ambient seawater and estimates of particulate organic matter incorporation by the sponges.

\section{MATERIALS AND METHODS}

Study site and sampling. Sponge and water samples were collected from deep water coral mounds on the southeastern part of Rockall Bank (Logachev mounds) from 24 June to 12 July 2005 (Fig. 1). Two complexes were visited, the Clan mounds (Artur mound $55.4444^{\circ} \mathrm{N}, 16.0755^{\circ} \mathrm{W}$ ) and the Haas mounds (center: $55.4944^{\circ} \mathrm{N}, 15.7894^{\circ} \mathrm{W}$ ), which lie approximately $20 \mathrm{~km}$ apart (Van Duyl \& Duineveld 2005). Coral mounds on the Rockall Bank slope rise up from $\sim 850-900 \mathrm{~m}$ to $550 \mathrm{~m}$ depth. Bottom water was collected on the mounds between 570 and $785 \mathrm{~m}$ depth using a $1000 \mathrm{l}$ water box whose lids closed when a mechanical release trigger touched the bottom. It collected water from $50 \mathrm{~cm}$ above the bottom. In addition, water samples were taken from approximately $2.5 \mathrm{~m}$ above the bottom at the Haas mound complex (Wmound $55.4948^{\circ} \mathrm{N}, 15.8059^{\circ} \mathrm{W}$ ) with a CTD array equipped with Noex water bottles. Seawater from the water box and the CTD array was collected in clean $1 \mathrm{l}$ polycarbonate bottles for immediate processing. A box corer (stainless steel cylindrical barrel: $50 \mathrm{~cm}$ inner diameter, $55 \mathrm{~cm}$ high) was used to collect intact bottom cores with overlying seawater. The box-core water was siphoned into a $5 \mathrm{l}$ glass bottle that had been rinsed with $0.1 \mathrm{M} \mathrm{HCl}$ and box-core water prior to sampling. The box-core water was usually very turbid and larger particles were allowed to settle for $1 \mathrm{~h}$ at the in situ temperature $\left(9^{\circ} \mathrm{C}\right)$ before subsampling. Water samples from the water box, the CTD water bottles and the box corer were analysed for inorganic nutrients, DOC and DIC, prokaryote abundance and production.

Box cores were screened for the presence of sponges. We selected 2 abundant sponge species, Higginsia thielei Topsent, 1904 (small, round, rigid, whitegreenish in color: Class Demospongiae, Order Halichondrida, Familiy Heteroxyidae) and Rossella nodastrella Topsent, 1915 (white, large, thin-walled tubular-trumpet shape: Class Hexactinellida, Order Lyssacinosida, Family Rossellidae) (Van Soest et al. 


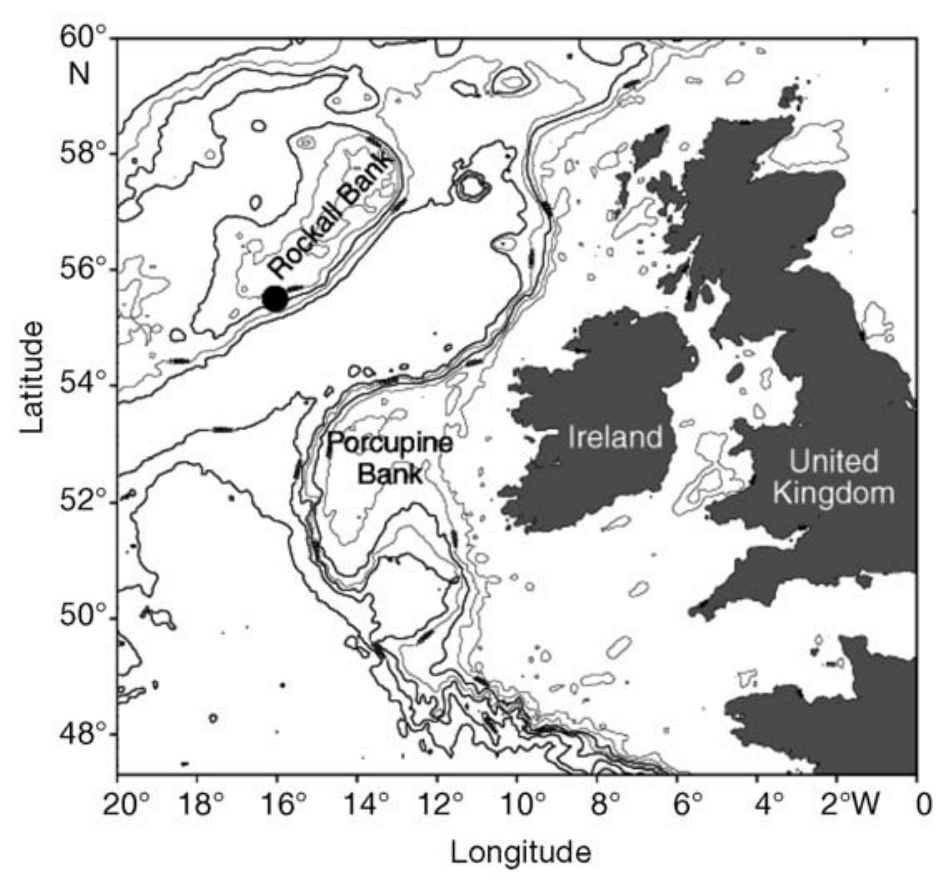

Fig. 1. Study site on the Rockall Bank slope in the NE Atlantic indicated by (๑)

2007b). H. thielei was collected in the Haas and Clan mound complexes between 570 and $785 \mathrm{~m}$ depth. $R$. nodastrella was collected by box core at $585 \mathrm{~m}$ depth and with a short trawl with a small triangular dredge at the Haas mound complex at around $529 \mathrm{~m}$ depth. Collected sponges were kept alive in tanks in a cool container at about $9^{\circ} \mathrm{C}$ until enough material was collected to start the incubation experiments (maximum $5 \mathrm{~d}$ holding time). Tank water was refreshed with bottom water every $2 \mathrm{~d}$.

Inorganic nutrients, dissolved organic and inorganic carbon. Duplicate water samples for $\mathrm{NH}_{4}{ }^{+}, \mathrm{NO}_{2}{ }^{-}$, $\mathrm{NO}_{\mathrm{x}}\left(=\mathrm{NO}_{2}{ }^{-}+\mathrm{NO}_{3}{ }^{-}\right)$, and $\mathrm{PO}_{4}{ }^{3-}$ were filtered over $0.2 \mu \mathrm{m}$ Acrodisc filters, collected in $6 \mathrm{ml}$ pony vials and stored at $4^{\circ} \mathrm{C}$. Within $15 \mathrm{~h}$ of collection, samples were analysed using a Technicon TRAACS 800 autoanalyzer according to Grasshoff et al. (1999). Samples for DIC were fixed with $10 \mu \mathrm{l}$ saturated $\mathrm{HgCl}_{2}$ solution using a $5 \mathrm{ml}$ glass vial filled to the rim to avoid inclusion of air. The DIC concentrations in the water were determined spectrophotometrically by a continuous flow set-up on a Technicon TRAACS 800 autoanalyzer (Stoll et al. 2001). DOC was gravity-filtered over $0.2 \mu \mathrm{m}$ polycarbonate filters. Filters were pre-washed 3 times with sterile $0.1 \mathrm{M} \mathrm{HCl}$ and subsequently twice with sample water before the DOC sample was collected. Twenty $\mathrm{ml}$ samples were pipetted into combusted glass ampoules and fixed with 5 drops of a 1:1 (v/v) phosphoric acid and Milli-Q water solution. Ampoules were sealed using a gas burner. DOC con- centrations were determined by high-temperature combustion on a Shimadzu TOC-5000.

Bottom water incubations with ${ }^{3} \mathrm{H}$-leucine and ${ }^{14} \mathrm{C}$ DIC. Heterotrophic prokaryote production was measured with ${ }^{3} \mathrm{H}$-leucine in the overlying seawater of the box core $(n=4)$, in seawater of the large water box ( $\mathrm{n}=8$ ), and in seawater of the CTD water bottles ( $\mathrm{n}=4)$. Duplicate samples of $10 \mathrm{ml}$ were incubated with a final concentration of $30 \mathrm{nM}$ leucine, of which $50 \%$ was labelled with ${ }^{3} \mathrm{H}$-leucine (Amersham Biosciences, specific activity $167 \mathrm{Ci} \mathrm{mmol}^{-1}$ ). Test experiments showed that a $30 \mathrm{nM}$ final concentration was sufficient to just saturate leucine uptake (authors' unpubl. data). Incubations with ${ }^{3} \mathrm{H}$-leucine were conducted at $9^{\circ} \mathrm{C}$ in the dark. Control samples were preincubated for $7 \mathrm{~min}$ with $0.5 \mathrm{ml}$ of $0.2 \mu \mathrm{m}$ filtered $37 \%$ formaldehyde before the radioactive label was added. Incubations lasted $2 \mathrm{~h}$ and were terminated by addition of $0.5 \mathrm{ml} 0.2 \mu \mathrm{m}$ filtered $37 \%$ formaldehyde $(2 \%$ final concentration). The proteins synthesized during the incubation were precipitated with ice-cold trichloroacetic acid (TCA, $5 \%$ solution) on a polycarbonate filter ( $0.2 \mu \mathrm{m}$ pore size, 3 washes) and subsequently washed with bacteria-free seawater. Filters were transferred to $20 \mathrm{ml}$ plastic scintillation vials and stored at $-20^{\circ} \mathrm{C}$ until analysis.

Incorporation of ${ }^{14} \mathrm{C}$-DIC into prokaryotic cells was determined in seawater samples of the water box ( $\mathrm{n}=5$ ). Using $50 \mathrm{ml}$ Greiner tubes, $50 \mu \mathrm{Ci}{ }^{14} \mathrm{C}$-labeled sodium bicarbonate was added to $50 \mathrm{ml}$ of seawater leaving negligible headspace to avoid degassing of $\mathrm{CO}_{2}$. Samples were incubated in triplicate in the dark at an in situ temperature $\left(9^{\circ} \mathrm{C}\right)$ and terminated at $t=0$ (control) and $t=72 \mathrm{~h}$ with $0.2 \mu \mathrm{m}$ filtered formaldehyde, $2 \%$ final concentration. Subsequently, the samples were filtered over a $0.2 \mu \mathrm{m}$ pore size polycarbonate filter and the free ${ }^{14} \mathrm{C}$-labeled and unlabeled $\mathrm{CO}_{2}$ was fumed from the sample in an excicator with concentrated $\mathrm{HCl}$ for 30 to $35 \mathrm{~min}$. Subsequently, filters were transferred to plastic scintillation vials and stored at $-20^{\circ} \mathrm{C}$ until analysis.

Radioactivity in filter samples was counted on a Wallac 1211 Rack Beta Scintillation Counter with an external standard. We added $10 \mathrm{ml}$ of Ultima Gold XR Scintillation cocktail to each filter and corrected for quench. Heterotrophic carbon incorporation was determined according to Simon \& Azam (1989) assuming an internal isotope dilution of 2. Total DIC fixation was based on the fraction of ambient DIC that was incorporated in biomass.

Sponge incubations with ${ }^{3} \mathrm{H}$-leucine and ${ }^{14} \mathrm{C}$-DIC. Intact live Higginsia thielei specimens with a maximum volume of $3.8 \mathrm{~cm}^{3}$ and pieces of live Rossella nodastrella with maximum volumes of $11 \mathrm{~cm}^{3}$ (carefully cut in filtered seawater) were used for the incuba- 
tions. The conditions of whole sponges and sponge pieces were judged on basis of color (sponges showing color shifts from white to brownish were not used), firmness of skeleton and absence of debris/sediment on skin and dermalia (protruding spicules). The absence of debris indicates that sponges are able to clean themselves. Only sponges that met these criteria were used for experiments. Biochemical tests revealed 2-5A synthetase activity and ATP N-glycosidase activity in $H$. thielei and $R$. nodastrella, demonstrating the presence of live sponge cells in our samples (M. Kelve pers. comm.). We did not observe active pumping in either sponge species. Whether or not there was sponge pumping during the dark incubations, we considered turbulence in $50 \mathrm{ml}$ Greiner incubation vials adequate to supply the sponge-microbe consortia with a passive flow of dissolved carbon.

Before the incubation experiments, sponges were carefully washed 3 times in ultra-filtered seawater. Sponge samples were placed in $50 \mathrm{ml}$ Greiner tubes with 20 or $50 \mathrm{ml}$ ultra-filtered seawater containing a natural DOC concentration of 70 to $80 \mu \mathrm{M}$ and incubated in the dark at in situ temperature $\left(9^{\circ} \mathrm{C}\right)$ with either ${ }^{3} \mathrm{H}$-leucine or ${ }^{14} \mathrm{C}$-sodium bicarbonate for 5 or $24 \mathrm{~h}$, respectively. The concentrations of radioactive label and leucine were those used for seawater samples. The controls consisted of sponges that were killed during a 5 to 10 min pre-incubation with formaldehyde ( $2 \%$ final concentration) before the radioactive label was added at $t=0$. To investigate the contribution of nitrification to chemolithoautotrophy in the ${ }^{14} \mathrm{C}$-bicarbonate incubations, we added a series of sponges spiked with allylthiourea $(10 \mu \mathrm{M})$ and/or ammonium sulfate $(10 \mu \mathrm{M})$. Allylthiourea is a selective inhibitor of ammonia oxidase (Bédard \& Knowles 1989) and thus inhibits the oxidation of ammonia to hydroxylamine $\left(\mathrm{NH}_{2} \mathrm{OH}\right)$, the first step in nitrification. Ammonium sulfate was added to prevent limitation of nitrification. After the incubations, live sample processes were terminated with formaldehyde, and the ambient seawater was filtered over $0.2 \mu \mathrm{m}$ polycarbonate filters to collect released tissue, associated prokaryotes and mucus. The organisms were washed in ultra-filtered seawater that was also collected on the filter. Subsequently, the tissue was hydrolyzed by heating the samples for $20 \mathrm{~min}$ in a $2 \mathrm{M} \mathrm{NaOH}$ solution at $90^{\circ} \mathrm{C}$. The hydrolyzed tissue was collected on $0.2 \mu \mathrm{m}$ polycarbonate filters. All particulate material associated with the sponge was accounted for in the activity estimations. The samples for protein synthesis analysis $\left({ }^{3} \mathrm{H}\right.$-leucine incorporation) were neutralized to $\sim \mathrm{pH} 7$ after the heat treatment, pipetted onto a polycarbonate filter and washed with ice-cold TCA to precipitate the proteins. Samples were further treated as for the seawater samples. For the calculations, we assumed that the conversion factors Simon \& Azam (1989) used to estimate biomass production for prokaryotes can also account for biomass production of the sponge-microbe consortia.

Samples of ${ }^{14} \mathrm{C}$-DIC incubations were hydrolyzed with $2 \mathrm{M} \mathrm{NaOH}$ for $20 \mathrm{~min}$, filtered over $0.2 \mu \mathrm{m}$ polycarbonate filters and washed with ultra-filtered seawater. To release unbound $\mathrm{CO}_{2}$, filters were fumed for 30 to $35 \mathrm{~min}$ with concentrated $\mathrm{HCl}(36 \%)$ in an excicator and stored in a freezer $\left(-20^{\circ} \mathrm{C}\right)$ for later analysis of incorporated ${ }^{14} \mathrm{C}$ in sponge biomass. Occasionally, DOM was collected to determine the ${ }^{14} \mathrm{C}$ radioactivity in excretion products and minute particles that passed through the $0.2 \mu \mathrm{m}$ pore polycarbonate filter. DOM samples were acidified in test tubes for several weeks and subsequently flushed to remove the unbound $\mathrm{CO}_{2}$. After the full treatment, filters and DOM samples were transferred to $20 \mathrm{ml}$ plastic scintillation vials and stored at $-20^{\circ} \mathrm{C}$ for later scintillation counting (see 'Bottom water incubations with ${ }^{3} \mathrm{H}$-leucine and ${ }^{14} \mathrm{C}$-DIC' above).

Ammonia oxidation by sponges. Higginsia thielei and Rossella nodastrella were incubated with and without $\left(\mathrm{NH}_{4}\right)_{2} \mathrm{SO}_{4}(10 \mu \mathrm{M})$, and with and without allylthiourea $(10 \mu \mathrm{M}$, a selective inhibitor of ammonia oxidation). Sponges and controls without sponge were incubated for $24 \mathrm{~h}$ in Greiner tubes containing $50 \mathrm{ml}$ ultra-filtered bottom water in the dark at in situ temperature $\left(9^{\circ} \mathrm{C}\right)$. Inorganic nutrients $\left(\mathrm{NH}_{4}{ }^{+}, \mathrm{NO}_{2}{ }^{-}, \mathrm{NO}_{3}{ }^{-}\right)$ were measured at $t=0$ and $t=24 \mathrm{~h}$ and a linear relation of change was assumed. The nitrite and ammonia release rates in the presence and absence of allylthiourea were determined. The sponge autotrophic ammonium oxidation rates were calculated as the difference between the net $\mathrm{NO}_{2}{ }^{-}$release rates with and without allylthiourea, respectively, divided by the sponge volume. The control (filtered water without sponge) was checked for ammonia oxidation to nitrite.

Volume, dry weight and $\mathrm{C}$ - and $\mathrm{N}$-contents of sponges. We measured with calipers the individual sponges or sponge pieces submerged in filtered seawater. The length, width and height were taken, occasionally at several distances along the main axes of the sponges to estimate volumes. The morphology of intact Higginsia thielei was variably characterized, depending on geometry, by a (truncated) cone, a sphere or a cylinder or a combination of 2 different or identical forms. For experiments with Rossella nodastrella, we cut the in situ vertical, peripheral curving wall into either circular or rectangular pieces of 5 to $12 \mathrm{~cm}^{2}$ and the average thickness of the slices was estimated by measuring the thickness in different slice sections.

For the analysis of dry weight and $\mathrm{C}$ and $\mathrm{N}$ contents of sponges, we stored frozen specimens until processing. Sponges were thawed, flushed with distilled water and blotted dry. Dry weight was determined after $48 \mathrm{~h}$ 
drying to constant weight in an oven at $50^{\circ} \mathrm{C}$. The carbon and nitrogen contents of sponge pieces were determined with a Carlo Erba Na-1500 HCN analyser (Verardo et al. 1990).

Abundances of prokaryotes in sponge tissue and ambient seawater. Sponge samples in $6 \mathrm{ml}$ pony vials were fixed with a 1:1 (v/v) phosphate buffered saline (PBS) and paraformaldehyde solution for at least $30 \mathrm{~min}$, but less than $12 \mathrm{~h}$, at $4^{\circ} \mathrm{C}$ in a refrigerator. After fixation, samples were washed twice with $1 \times$ PBS and stored at $-20^{\circ} \mathrm{C}$ in $6 \mathrm{ml}$ pony vials with PBS:ethanol (1:1 v/v). For dissociation of sponge cells and harvesting of associated prokaryotic cells, we adjusted the protocol of Müller et al. (1999). Sponge samples were cut in small pieces of ca. $50 \mathrm{~mm}^{3}$. Samples were blotted dry and wet weights (wet wt) were determined. To tissue portions of 40 to $80 \mathrm{mg}$ wet $\mathrm{wt}_{1} 5 \mathrm{ml}$ of calcium and magnesium free artificial seawater (CMFSW) with EDTA solution (CMFSW+E: $540 \mathrm{mM} \mathrm{NaCl}, 10 \mathrm{mM}$ $\mathrm{KCl}, 7 \mathrm{mM} \mathrm{Na}_{2} \mathrm{SO}_{4}, 0.2 \mathrm{mM} \mathrm{NaHCO}, 20 \mathrm{mM}$ Tris, 20mM EDTA) were added and the tubes were gently shaken for $40 \mathrm{~min}$. The supernatant was transferred to a $50 \mathrm{ml}$ Greiner tube. The cycle of adding CMFSW+E, shaking and collection of supernatant from the sponge tissue was repeated 8 times. In the 1 st and 4 th cycles, samples were sonificated (output: $6 \mathrm{~W} ; 12 \mathrm{~s}$ on, $16 \mathrm{~s}$ off; 7 cycles) to loosen the tissue. After tissue dissociation, total volume of supernatant collected was determined and filtered through a nylon mesh $(20 \mu \mathrm{m})$.

Seawater samples from the box cores $(20 \mathrm{ml})$ were fixed with $1.2 \mathrm{ml}$ of $0.2 \mu \mathrm{m}$ filtered formaldehyde (37\%) for at least $1 \mathrm{~h}$, but no longer than $24 \mathrm{~h}$. The samples were subsequently filtered over a white $0.2 \mu \mathrm{m}$ polycarbonate filter (GTTP) on a support filter (0.45 $\mathrm{mm}$ cellulose nitrate). After filtration, the filters were rinsed with 5 to $10 \mathrm{ml} \mathrm{MQ}$ water and air-dried. The filters were stored in $2 \mathrm{ml}$ Eppendorf cups at $-20^{\circ} \mathrm{C}$ until processing.

Water samples from the water box and CTD bottles $(10 \mathrm{ml})$ were fixed with $0.8 \mathrm{ml} 0.2 \mu \mathrm{m}$ filtered glutaraldehyde $(25 \%)$ and stained in darkness with a $2.5 \mathrm{ml}$ DAPI solution (10 ml MacIlvain buffer with $200 \mu \mathrm{l}$ DAPI solution at a concentration of $5 \mathrm{mg} \mathrm{ml}^{-1}$ ) for at least $30 \mathrm{~min}$, but no longer than $24 \mathrm{~h}\left(4^{\circ} \mathrm{C}\right.$ in a refrigerator) (Porter \& Feig 1980). After staining, samples were filtered over a black $0.2 \mu \mathrm{m}$ polycarbonate filter supported by a $0.45 \mu \mathrm{m}$ pore size cellulose nitrate filter and air-dried. Filters were mounted in immersion oil and stored at $-20^{\circ} \mathrm{C}$ until counting.

Prokaryotes in the dissociated sponge tissue and in the ambient seawater of the same box cores were double stained with DAPI and catalyzed reporter deposition fluorescent for in situ hybridization (CARD-FISH). Total counts of prokaryotes were made with the DAPI staining, while the molecular probes applied with the
CARD-FISH method distinguished between Bacteria and Archaea. The following probes were used: EUBIIII mix for Bacteria and Cren537 and Eury806 for Crenarchaeota and Euryarchaeota, respectively. All filters for CARD-FISH were embedded in $0.1 \%$ agarose and dried at $37^{\circ} \mathrm{C}$. For the full protocol of permeabilization, hybridization and amplification of the prokaryotes on the filters see Teira et al. (2004).

Filters were counted under a Zeiss Axioplan or Zeiss Axiovert epifluorescence microscope with a DAPI and FITC filter and a Plan-Neofluar objective. Up to 60 fields filter ${ }^{-1}$ were counted, or 20 fields when fields contained 10 or more prokaryotes on average. Replicate counts were made on each sponge filtrate or water sample. For estimating the prokaryotic biomass, we assumed a C content of $10 \mathrm{fg} \mathrm{C} \mathrm{cell}{ }^{-1}$ (Ducklow 2000).

Statistical analyses. Data were analysed using standard statistical tests (SYTAT ${ }^{\circledR}$ 10). We ran 1-sided, 2-sided and full ANOVAs (general linear models) on flux data to assess the effects of (1) chemical treatment, (2) method of collection of sponges and (3) sponge species on ln-transformed leucine incorporation and $\mathrm{CO}_{2}$ fixation rates by sponges. With the transformation, normal distribution of the flux data was obtained. For comparison of fluxes in live and dead sponges, we applied a 1-sided probability test and rejected the null hypothesis (no difference) when $\mathrm{p} \leq 0.05$. In the comparison of live treatments, we considered a 2-sided probability of $<0.1$, but $>0.05$ as significant.

\section{RESULTS}

\section{Bottom water characteristics}

The nutrient concentrations in bottom water of coral mounds with live corals and sponges between 560 and $781 \mathrm{~m}$ depth are presented in Table 1. The box-core water samples were particularly enhanced in $\mathrm{PO}_{4}{ }^{3-}$, $\mathrm{NH}_{4}{ }^{+}$and DOC compared with the Noex bottle CTD and water box samples. The physical impact of the box core on the bottom induced resuspension of material in the overlying water. The CTD samples were taken 4 times at $581 \mathrm{~m}$ depth at the same location over $24 \mathrm{~h}$. The clustered CTD sampling in space and time is reflected in the low SDs of the variables measured. In situ temperatures were measured only with the CTD and with temperature sensors connected to landers (Duineveld et al. 2004). During the tidal cycle, temperature varied from 8.4 to $9.7^{\circ} \mathrm{C}$ (CTD measurements 10 to 11 July 2005). The water samples taken with the water box were different from those of the other 2 devices. Based on the significantly lower $\mathrm{NO}_{3}{ }^{-}$concentrations, it is likely that the water box leaked and exchanged water with ambient water during transit to the ship. 
Table 1. Mean nutrient concentrations in bottom water collected above coral mounds with 3 different sampling devices (see 'Materials and methods; study site and sampling' for explanation). All chemical concentrations in $\mu \mathrm{M}$. DIC: dissolved inorganic carbon, DOC: dissolved organic carbon

\begin{tabular}{|c|c|c|c|c|c|c|c|c|c|}
\hline & \multirow{2}{*}{\multicolumn{2}{|c|}{$\begin{array}{c}\text { Box core } \\
\text { Mean }\end{array}$}} & \multirow[b]{2}{*}{$\mathrm{SD}$} & \multicolumn{3}{|c|}{ — Noex bottle CTD } & \multirow[b]{2}{*}{$\mathrm{n}$} & \multirow{2}{*}{$\begin{array}{l}\text { Water box } \\
\text { Mean }\end{array}$} & \multirow[b]{2}{*}{$\mathrm{SD}$} \\
\hline & & & & $\mathrm{n}$ & Mean & SD & & & \\
\hline Depth (m) & 8 & 685 & 85 & 4 & 581 & 13 & 8 & 649 & 89 \\
\hline Temp. $\left({ }^{\circ} \mathrm{C}\right)$ & - & - & - & 4 & 8.81 & 0.40 & - & - & - \\
\hline $\mathrm{PO}_{4}{ }^{3-}$ & 8 & 1.101 & 0.162 & 4 & 0.958 & 0.064 & 8 & 0.747 & 0.084 \\
\hline $\mathrm{NH}_{4}^{+}$ & 8 & 0.298 & 0.085 & 4 & 0.140 & 0.022 & 8 & 0.155 & 0.046 \\
\hline $\mathrm{NO}_{2}^{-}$ & 8 & 0.078 & 0.025 & 4 & 0.050 & 0.004 & 8 & 0.092 & 0.022 \\
\hline $\mathrm{NO}_{3}^{-}$ & 8 & 14.685 & 1.111 & 4 & 15.080 & 0.963 & 8 & 11.937 & 1.373 \\
\hline DIC & 8 & 2172.0 & 5.0 & - & - & - & - & - & - \\
\hline DOC & 5 & 73.0 & 6.0 & 4 & 51.0 & 2.6 & 6 & 55.0 & 4.7 \\
\hline
\end{tabular}

Table 2. Dissolved organic (DOC) and inorganic (DIC) carbon incorporation, prokaryote abundance and production in bottom water collected over coral mounds using 3 sampling devices. Values in parentheses are sample sizes. DIC fixation in the water box samples (WK) was also used in the calculations of total dissolved carbon incorporation (TDC) in box core and CTD water samples

\begin{tabular}{|c|c|c|c|c|c|c|c|c|c|c|}
\hline & $\begin{array}{l}\text { Depth } \\
\text { range } \\
(\mathrm{m})\end{array}$ & $\begin{array}{c}\text { DOC incorp. } \\
\left(\mathrm{nmol} \mathrm{cm}^{-3}\right. \\
\left.\mathrm{d}^{-1}\right)\end{array}$ & $\begin{array}{c}\text { DIC fix. } \\
\left(\mathrm{nmol} \mathrm{cm}^{-3}\right. \\
\left.\mathrm{d}^{-1}\right)\end{array}$ & $\begin{array}{l}\text { TDC incorp. } \\
\left(\mathrm{nmol} \mathrm{cm}^{-3}\right. \\
\left.\mathrm{d}^{-1}\right)\end{array}$ & $\begin{array}{l}\text { DIC fix. as pro- } \\
\text { portion of TDC } \\
\text { incorp. }(\%)\end{array}$ & $\begin{array}{c}\text { DAPI } \\
\text { counts } \\
\left(\mathrm{n} \mathrm{cm}^{-3}\right)\end{array}$ & $\begin{array}{c}\text { Biomass } \\
(\mathrm{nmol} \\
\left.\mathrm{C} \mathrm{cm}^{-3}\right)\end{array}$ & $\begin{array}{l}\text { Specific } \\
\text { growth } \\
\left(\mathrm{d}^{-1}\right)\end{array}$ & $\begin{array}{l}\text { Doubling } \\
\text { time } \\
\text { (d) }\end{array}$ & $\begin{array}{l}\text { Cell-specific } \\
\text { prod. (fmol C } \\
\left.\text { cell }^{-1} \mathrm{~d}^{-1}\right)\end{array}$ \\
\hline Box core & $724 \pm 94$ & $0.04(4)$ & - & 0.04 & - & $3.58 \times 10^{5}(4)$ & 0.30 & 0.15081 & 4.6 & 0.12567 \\
\hline CTD & $581 \pm 13$ & $0.03(3)$ & - & 0.04 & - & $3.10 \times 10^{5}(4)$ & 0.26 & 0.15145 & 4.6 & 0.12621 \\
\hline WK & $649 \pm 89$ & $0.11(8)$ & $0.0043(4)$ & 0.11 & 4 & $4.91 \times 10^{5}(8)$ & 0.41 & 0.26986 & 2.6 & 0.22488 \\
\hline
\end{tabular}

The total microbial production in bottom water ranged from 0.04 to $0.11 \mathrm{nmol} \mathrm{C} \mathrm{cm}^{-3} \mathrm{~d}^{-1}$ at a microbial abundance of 3.1 to $4.9 \times 10^{5}$ microbes $\mathrm{cm}^{-3}$, with the higher values in water box samples (Table 2) in which the production and abundance were, on average, ca. 3fold and up to 1.6-fold higher, respectively, than in the box core and Noex bottle CTD water samples. DIC fixation was measured only in the water box samples. For the specific growth rates of prokaryotes, we summed heterotrophic production based on leucine incorporation and DIC fixation (as measured in the water box) of prokaryotes. DIC fixation was $4 \%$ of the total prokaryotic biomass production in the water box (Table 2).

\section{${ }^{3} \mathrm{H}$-leucine incorporation by sponge-microbe consortia}

The incubations of intact live Higginsia thielei and pieces of live Rossella nodastrella with ${ }^{3} \mathrm{H}$-leucine in filtered seawater demonstrated a significant incorporation of leucine compared to the control incubations (with formaldehyde) ( $H$. thielei, Fig. 2a: ANOVA, $F_{1,8}=$ 23.8, $\mathrm{n}=10, \mathrm{p}<0.05$; $R$. nodastrella, Fig. 2b, c: ANOVA, $\left.F_{1,10}=8.473, \mathrm{n}=12, \mathrm{p}<0.05\right)$. Control incubation levels were relatively high, suggesting that pre-incubations with formaldehyde for 5 to 10 min may have been too short, or the final concentration of $2 \%$ was too low to kill the sponges. Most of the leucine incorporated into proteins was associated with the hydrolysed tissue (mean $\pm \mathrm{SD} ; 79 \pm 17 \%$ in $H$. thielei and $57 \pm 24 \%$ in $R$. nodastrella). The remainder of the incorporated leucine was found in released particulate matter, which was collected on filters before hydrolysis. Leucine incorporation rates into protein (including a 2 -fold isotope dilution) were on average $0.031 \mathrm{nmol}$ leucine $\mathrm{cm}^{-3}$ sponge $\mathrm{d}^{-1}$ for $H$. thielei $\left(=4 \mathrm{nmol} \mathrm{C} \mathrm{cm}{ }^{-3}\right.$ sponge $\mathrm{d}^{-1}$ ) and 0.014 and $0.028 \mathrm{nmol}$ leucine $\mathrm{cm}^{-3}$ sponge $\mathrm{d}^{-1}$ for box-cored and dredged $R$. nodastrella (= 2 and $4 \mathrm{nmol} \mathrm{cm}^{-3}$ sponge $\mathrm{d}^{-1}$ ), respectively. Rates measured in pieces of the dredged $R$. nodastrella were slightly higher than rates in the box-cored specimen. Rates per unit volume of sponge were 50 to 100 times higher than in the ambient water. DOC concentration in ultra-filtered incubation water ranged from 69 to $81 \mu \mathrm{M}$, and was comparable to reef ambient DOC concentrations $($ mean $=73 \mu \mathrm{M}$ in box-core water).

\section{${ }^{14} \mathrm{C}$-DIC fixation by sponge-microbe consortia}

The different live treatments (with and without allylthiourea and with and without ammonium sulfate) had no significant effect on DIC incorporation by Higginsia thielei (Fig. 3a) (1-way ANOVA, n = 18, p > 0.10) and Rossella nodastrella (Fig. 3b,c) (2-way ANOVA, treatment and method, $\mathrm{n}=17, \mathrm{p}>0.10)$. The large variations between different incubations within one treat- 

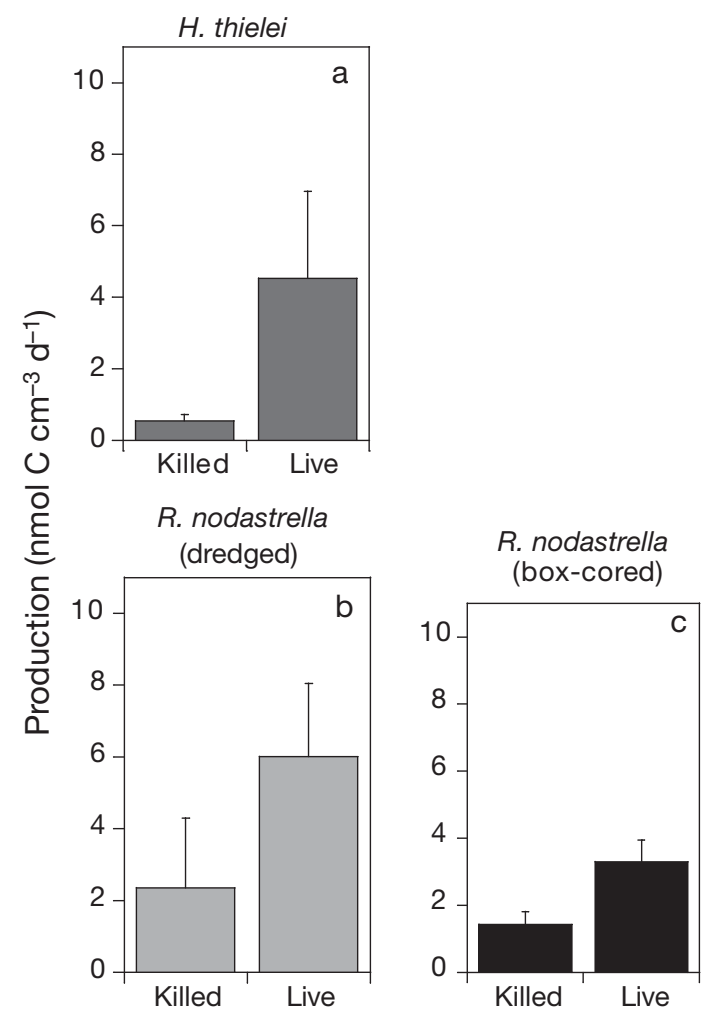

Fig. 2. Mean estimates (+SD) of sponge-microbe consortium production derived from ${ }^{3} \mathrm{H}$-leucine incorporation measurements. Carbon incorporation in sponges killed at $t=0$ was compared with incorporation in live sponges: (a) Higginsia thielei (killed: $\mathrm{n}=5$; live: $\mathrm{n}=6$ ). Specimens were collected from different box cores. (b) Rossella nodastrella pieces (killed: $\mathrm{n}=3$; live: $\mathrm{n}=3$ ) from 1 specimen collected by dredging; (c) Rossella nodastrella pieces (killed: $\mathrm{n}=3$; live $\mathrm{n}$ : $=3$ ) from 1 box-core specimen

ment may be due to the fact that they were all performed with different individuals or sponge pieces. Moreover, 'killed' controls appeared to fix $\mathrm{CO}_{2}$, reducing the difference between presumed dead and live sponges. Since there were no significant differences between live treatments, we tested the difference in $\mathrm{CO}_{2}$ fixation between live and 'killed' sponges. Overall, the average DIC fixation in live intact $H$. thielei specimens significantly exceeded that of the 'killed' controls (1-way ANOVA, 1-sided probability, $\mathrm{n}=24$, $\mathrm{p}=0.05)$. The average net $\mathrm{CO}_{2}$ fixation by $H$. thielei was $0.7 \pm 0.8 \mathrm{nmol} \mathrm{C} \mathrm{cm} \mathrm{C}^{-3} \mathrm{~d}^{-1}$, which was on average up to 170 times higher than the $\mathrm{CO}_{2}$ fixation by prokaryotes in ambient bottom water. Live pieces of dredged and box-cored $R$. nodastrella had significant net DIC fixation compared with the killed controls (Fig. 3b,c) (2-way ANOVA, 1-sided probability; treatment $F_{1,9}=5.416, \mathrm{p}<0.05 ;$ method $F_{1,19}=361.02, \mathrm{p}<$ 0.05 ; treatment $\times$ method $F_{1,19}=2.167, \mathrm{p}>0.1 ; \mathrm{n}=23$ ). The interaction between collection method and treat- ment was not significant, implying that variations in $\mathrm{CO}_{2}$ fixation by $R$. nodastrella were determined by the main effects (method and treatment). The incorporation of bicarbonate by dredged $R$. nodastrella (mean \pm

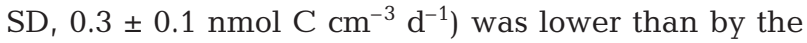
box-cored specimen. The box-cored $R$. nodastrella fixed $4.5 \pm 5.3 \mathrm{nmol}$ DIC $\mathrm{cm}^{-3} \mathrm{~d}^{-1}$, which is approximately $10^{3}$-fold higher than the DIC fixation rate of prokaryotes in the ambient bottom water.

Across all live sponge incubations without allylthiourea shown in Fig. 3, the incubations with $\left(\mathrm{NH}_{4}\right)_{2} \mathrm{SO}_{4}$ were slightly higher than the live sponge incubations without $\left(\mathrm{NH}_{4}\right)_{2} \mathrm{SO}_{4}$. This difference was not significant within sponge species or within sampling methods (dredging or box coring). However, after combining the data from different sponge species and collection methods, the ammonium addition contributed significantly to the variation in $\mathrm{CO}_{2}$ fixation (GLM, 2-sided probability; species $F_{1,16}=139.090$, $\mathrm{p}<0.05$; method $F_{1,16}=346.956, \mathrm{p}<0.05$; treatment $\left.F_{1,16}=3.313,0.5<\mathrm{p}<0.1 ; \mathrm{n}=19\right)$. Interactions between species, method and treatment were not significant. This implies that $\left(\mathrm{NH}_{4}\right)_{2} \mathrm{SO}_{4}$ stimulated $\mathrm{CO}_{2}$ fixation by the sponge-microbe consortia.

Most DIC fixation in tissue was found in the hydrolysed tissue of the sponges (mean $\pm \mathrm{SD}, 74 \pm 14 \%$ in Higginsia thielei, and $61 \pm 4 \%$ for dredged and $53 \pm$ $13 \%$ for box-cored Rossella nodastrella, respectively); the remainder was recovered in particulate matter filtered before tissue hydrolysis. Dissolved ${ }^{14} \mathrm{C}$-labeled metabolites released during incubation were not accounted for in the average DIC fixation rates presented in Fig. 3, but were found to contribute substantially to the total DIC incorporated. More than $80 \%$ of the DIC fixed was recovered in the DOC fraction of live $H$. thielei incubations $(\mathrm{n}=5)$ and $77 \%$ of live dredged $R$. nodastrella incubations $(\mathrm{n}=3$ ) after correction for controls (authors' unpubl. data). This implies that we have underestimated $\mathrm{CO}_{2}$ fixation rates by a factor of 5 .

\section{Ammonia oxidation by sponge-microbe consortia}

The presence of sponge specimens in incubation tubes resulted in inorganic $\mathrm{N}$ concentration increases over the $24 \mathrm{~h}$ incubation period. $\mathrm{NH}_{4}{ }^{+}, \mathrm{NO}_{2}{ }^{-}, \mathrm{NO}_{3}{ }^{-}$did not significantly change in the absence of sponges. The net ammonium release rate (mean \pm SD), by Higginsia thielei was $999 \pm 330 \mathrm{nmol} \mathrm{cm}{ }^{-3} \mathrm{~d}^{-1}(\mathrm{n}=4)$ and $36 \pm 13 \mathrm{nmol} \mathrm{cm}^{-3} \mathrm{~d}^{-1}$ ( $\mathrm{n}=7$ ) by the dredged Rossella nodastrella. No consistent effects of the treatments $\left(\left(\mathrm{NH}_{4}\right)_{2} \mathrm{SO}_{4}\right.$ and/or allylthiourea) were found on the $\mathrm{NH}_{4}{ }^{+}$release by sponges. $H$. thielei excreted more $\mathrm{N}$ than it could have taken up under natural conditions, 

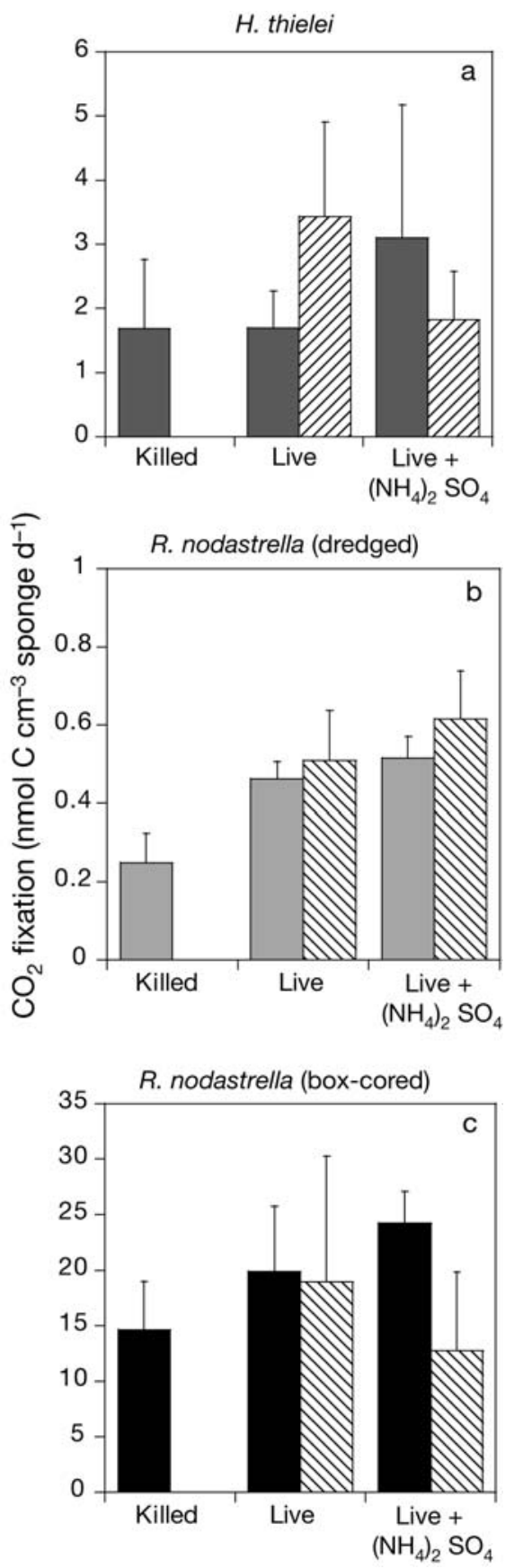

Fig. 3. Mean rates $(+\mathrm{SD})$ of bicarbonate fixation in spongemicrobe consortia. Fixation in killed sponges at $t=0$ was compared with fixation in live sponges. Live sponges were incubated without allylthiourea (grey or black bars) and with allylthiourea (striped bars). $\left(\mathrm{NH}_{4}\right)_{2} \mathrm{SO}_{4}$ was added in one series to prevent potential $\mathrm{NH}_{4}{ }^{+}$limitation of nitrification. (a) Higginsia thielei. Specimens were from different box cores, killed: $\mathrm{n}=6$; live without allylthiourea: $\mathrm{n}=6$; per treatment with allylthiourea and/or $\left(\mathrm{NH}_{4}\right)_{2} \mathrm{SO}_{4}: \mathrm{n}=4$. (b) Rossella nodastrella pieces were from 1 specimen collected by dredging, killed: $\mathrm{n}=3 ; \mathrm{n}=2$ per live treatment. (c) $R$. nodastrella pieces were from 1 box core specimen, killed: $\mathrm{n}=3$; live without allylthiourea: $\mathrm{n}=3$; else per live treatment: $\mathrm{n}=2$
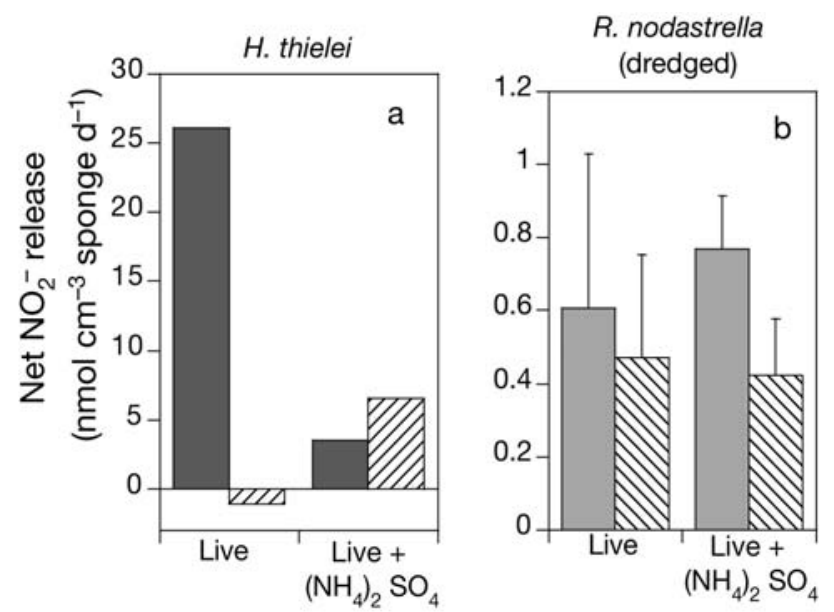

Fig. 4. Net $\mathrm{NO}_{2}{ }^{-}$release by live sponges. Live sponges were incubated without (grey bars) and with (striped bars) allylthiourea. $\left(\mathrm{NH}_{4}\right)_{2} \mathrm{SO}_{4}$ was added in one series to prevent potential $\mathrm{NH}_{4}{ }^{+}$limitation of nitrification. (a) Higginsia thielei specimens were from different box cores; 1 sponge was incubated per treatment. (b) Rossella nodastrella pieces were from 1 specimen collected with a dredge; $\mathrm{n}=2$, values: mean + range

and there may have been tissue degeneration during the incubation. Nitrite was released in all but one incubation ( $H$. thielei, live with allylthiourea), indicating ammonia oxidation to nitrite (Fig. 4a,b). Net rates varied from -1 to $26 \mathrm{nmol} \mathrm{NO} \mathrm{cm}^{-3}$ sponge $\mathrm{d}^{-1}$ for $H$. thielei and 0.4 to $0.8 \mathrm{nmol} \mathrm{NO}_{2} \mathrm{~cm}^{-3}$ sponge $\mathrm{d}^{-1}$ for the dredged $R$. nodastrella. $\left(\mathrm{NH}_{4}\right)_{2} \mathrm{SO}_{4}$ addition did not enhance the release rates of $\mathrm{NO}_{2}^{-}$by sponges. Allylthiourea addition inhibited nitrite release rates in $R$. nodastella. In $H$. thielei the effect of allylthiourea was only evident in the incubation without $\left(\mathrm{NH}_{4}\right)_{2} \mathrm{SO}_{4}$. Preliminary estimates of sponge nitrification were made by subtracting the effluxes of $\mathrm{NO}_{2}{ }^{-}$in the presence and absence of allylthiourea (Table 3). For comparison, we also added the net release of nitrite from the sponges as a measure of nitrification. No ammonia oxidation could be established in the ultra-filtered seawater used for the sponge incubations.

\section{Dry weight and carbon and nitrogen contents of sponges}

Dry weights $\mathrm{cm}^{-3}$ sponge were derived from the relation between volume and dry weight (dry wt) for each sponge species. The average dry wt of Higginsia thielei was $143 \mathrm{mg} \mathrm{cm}^{-3}$ sponge $(y=-19+162 x, \mathrm{r}=$ $0.85, \mathrm{n}=6$ ). The dry wt of Rossella nodastrella was lower, with an average of $126 \mathrm{mg} \mathrm{cm}^{-3}$ sponge $(y=109$ $+17 x_{1}, \mathrm{r}=0.78, \mathrm{n}=21$ ). Variations in dry $\mathrm{wt}^{\mathrm{cm}^{-3}}$ sponge were large due to the difficulty of making cor- 
Table 3. Higginsia thielei and Rossella nodastrella. Nitrification rates based on the difference in nitrite release rate of sponges in the presence and absence of allylthiourea and on the net nitrite release rates. $\left(\mathrm{NH}_{4}\right)_{2} \mathrm{SO}_{4}$ was added to half of the incubations to prevent potential $\mathrm{NH}_{4}{ }^{+}$limitation of nitrification

\begin{tabular}{|lccc|}
\hline Treatment & $\mathrm{n}$ & $\begin{array}{r}\text { Nitrification rate }\left(\mathrm{nmol} \mathrm{cm}^{-3} \text { sponge } \mathrm{d}^{-1} \text { ) }\right. \\
\text { Allylthiourea }\end{array}$ \\
\multicolumn{5}{|c}{ Net nitrite release } \\
\hline H. thielei (box-cored) & & \\
None & 1 & 27.1 & 26.10 \\
$\left(\mathrm{NH}_{4}\right)_{2} \mathrm{SO}_{4}$ & 1 & 0 & 3.53 \\
R. nodastrella (dredged) & & 0.61 \\
None & 2 & 0.13 & 0.77 \\
$\left(\mathrm{NH}_{4}\right)_{2} \mathrm{SO}_{4}$ & 2 & 0.34 & \\
\hline
\end{tabular}

rect volume estimations of the sponges, in particular for $R$. nodastrella. The organic carbon contents (mean $\pm \mathrm{SD}$ ) of sponges were $5.75 \pm 0.99$ and $5.15 \pm 1.85 \%$ of the dry wt of $H$. thielei and $R$. nodastrella, respectively. This implies an average organic C-content of $8.2 \mathrm{mg} \mathrm{C}$ $\mathrm{cm}^{-3}$ for $H$. thielei $\left(=685 \mu \mathrm{mol} \mathrm{C} \mathrm{cm} \mathrm{cm}^{-3}\right)$ and $6.5 \mathrm{mg} \mathrm{C}$ $\mathrm{cm}^{-3}$ for $R$. nodastrella ( $=542 \mu \mathrm{mol} \mathrm{C} \mathrm{cm}{ }^{-3}$ ). The molar organic C:N ratio was $4.6 \pm 0.8$ for $H$. thielei and $5.2 \pm$ 0.5 for $R$. nodastrella.

\section{Prokaryote abundances in sponges and sponge contact water}

Numbers of prokaryotes in different specimens of Higginsia thielei varied from $7.12 \times 10^{7}$ to $4.05 \times 10^{8}$ cells $\mathrm{cm}^{-3}$ (mean $=2.00 \times 10^{8}$ cells $\mathrm{cm}^{-3}$, Table 4). Rossella nodastrella harbored, on average, more prokaryotes than $H$. thielei and contained $1.3 \times 10^{8}$ to $3.4 \times 10^{8}$ cells cm${ }^{-3}$ (mean $=2.53 \times 10^{8}$ cells $\left.\mathrm{cm}^{-3}\right)$. When $R$. nodastrella was present, prokaryotic counts were higher in box-core water (sponge contact water) than in the absence of this sponge. This was not the case for $H$. thielei (Tables $2 \& 4$ ). Box cores containing $R$. nodastrella were not used for the counts in Table 2 . $R$. nodastrella and $H$. thielei were found in 13 and $38 \%$ of box cores collected over coral mounds, respectively.
Both sponges harbored Archaea (Cren- and Euryarchaea) and Bacteria. Cells of Bacteria were more abundant than those of Archaea in both sponges (means $=48 \%$ of DAPI counts in $H$. thielei and $55 \%$ in R. nodastrella). The abundances of Crenarchaea and Euryarchaea were 12 and $7 \%$ of the DAPI counts, respectively in $H$. thielei and 9 and $2 \%$, respectively, in R. nodastrella. Approximately 30 to $40 \%$ of the DAPI counts of sponge-associated prokaryotes could not be identified with the bacterial and archaeal CARD-FISH probes applied. In the sponge contact water, Archaea cells were present in only $2 \%$ of the total DAPI count; Bacteria made up ca. $30 \%$. The proportion of cells in the total count stained with CARD-FISH was much lower in the ambient water than in the sponges. The abundance of prokaryotes associated with sponges was on average 500 to 640 times higher than the abundance of planktonic prokaryotes in sponge contact water (Table 4). Prokaryotes amounted to $2 \mu \mathrm{g} \mathrm{C} \mathrm{cm}^{-3}$ in Higginsia and $2.5 \mu \mathrm{g} \mathrm{C} \mathrm{cm}{ }^{-3}$ in Rossella (based on the average $\mathrm{C}$-content of prokaryotes in oceanic waters, viz. $10 \mathrm{fg} \mathrm{C} \mathrm{Cell}^{-1}$; Ducklow 2000). These values represent 0.024 and $0.039 \%$ of the total organic carbon content of $H$. thielei and $R$. nodastrella, respectively.

\section{Specific growth rates of sponge-microbe consortia}

In Table 5, there is an overview of carbon production rates of the sponge-microbe consortia of Higginsia thielei and Rossella nodastrella in ultra-filtered seawater. The ${ }^{14} \mathrm{C}$-DIC incubations with allylthiourea are paired with the respective treatments without allylthiourea (i.e. without and with $\left.\left(\mathrm{NH}_{4}\right)_{2} \mathrm{SO}_{4}\right)$. The stimulating effect of $\left(\mathrm{NH}_{4}\right)_{2} \mathrm{SO}_{4}$ addition on the bicarbonate fixation remained (Table 5). Specific growth rates were based on 'total dissolved carbon incorporation', which is defined as the sum of the leucine based carbon production and the DIC fixation divided by the carbon content of the holobiont (sponge and spongeassociated prokaryotes) and the carbon content of associated prokaryotes, respectively. It is evident that

Table 4. Higginsia thielei and Rossella nodastrella. Abundances of associated prokaryotes in sponges and planktonic prokaryote abundances in sponge contact water (overlying boxcore water)

\begin{tabular}{|c|c|c|c|c|c|c|c|c|c|}
\hline & \multicolumn{3}{|c|}{ — Prokaryotes $\left(\mathrm{n} \mathrm{cm}^{-3}\right)$} & \multicolumn{3}{|c|}{ - Bacteria (\%) } & \multicolumn{3}{|c|}{ - Archaea (\%) } \\
\hline & $\mathrm{n}$ & Mean & $\mathrm{SD}$ & $\mathrm{n}$ & Mean & Range & $\mathrm{n}$ & Mean & Range \\
\hline \multicolumn{10}{|c|}{ Sponge associated } \\
\hline H. thielei & 5 & $2.00 \times 10^{8}$ & $1.36 \times 10^{8}$ & 5 & 48 & $36-52$ & 3 & 18 & $7-30$ \\
\hline R. nodastrella & 3 & $2.53 \times 10^{8}$ & $1.07 \times 10^{8}$ & 3 & 55 & $40-65$ & 3 & 11 & $7-17$ \\
\hline \multicolumn{10}{|c|}{ Sponge-contact water } \\
\hline H. thielei & 5 & $3.14 \times 10^{5}$ & $1.48 \times 10^{5}$ & 3 & 28 & $24-34$ & 3 & 2 & $1-3$ \\
\hline R. nodastrella & 3 & $4.83 \times 10^{5}$ & $1.47 \times 10^{5}$ & 3 & 32 & $25-38$ & 3 & 2 & $1-4$ \\
\hline
\end{tabular}


Table 5. Higginsia thielei and Rossella nodastrella. Overview of dissolved organic (DOC) and inorganic (DIC) carbon incorporation, biomasses of the holobionts and associated prokaryotes and related specific growth rates (SGR). DIC fixation was measured in 2 treatments, without (none) and with $\left(\mathrm{NH}_{4}\right)_{2} \mathrm{SO}_{4}$ additions (none), and DOC incorporation in only one treatment (none). To estimate total dissolved carbon (TDC) incorporation, the respective DOC incorporation without $\left(\mathrm{NH}_{4}\right)_{2} \mathrm{SO}_{4}$ addition was added to the DIC fixation with $\left(\mathrm{NH}_{4}\right)_{2} \mathrm{SO}_{4}$ addition. For the SGR calculations, the average biomasses of holobionts and associated prokaryotes were used.

Prod. = production. Values in parentheses are sample sizes

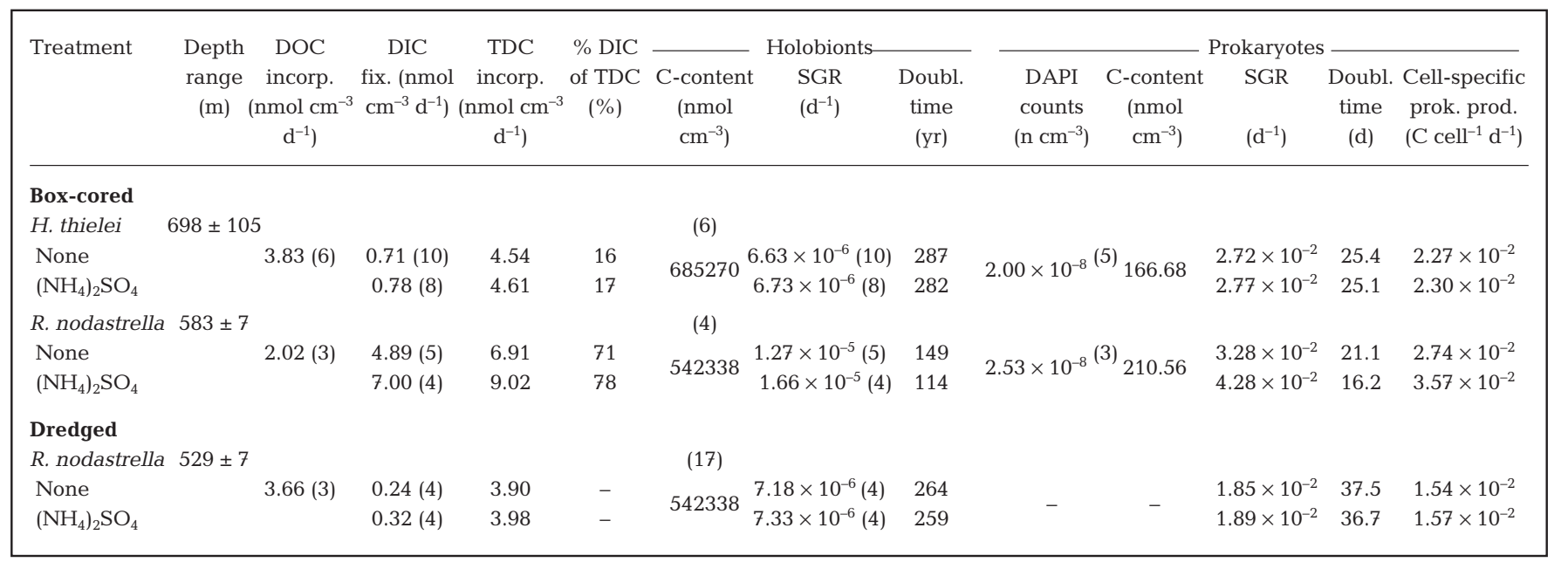

sponges cannot grow quickly on ambient DOC and DIC. Up to $287 \mathrm{yr}$ are required for biomass doubling at these uptake rates. If DOC and DIC incorporations are attributable to associated prokaryotes only, we arrive at specific growth rates of 0.02 to $0.04 \mathrm{~d}^{-1}$, which are 3 to 15 times slower than the specific growth rate of prokaryotes in ambient water (Table 2). The contribution of DIC fixation to the total dissolved carbon incorporation differed between $H$. thielei and $R$. nodastrella; in $R$. nodastrella production on DOC and DIC was dominated by DIC-fixation (70 to $80 \%$ ). Specific growth was highest for the box-cored $R$. nodastrella and lowest in the dredged $R$. nodastrella (due to the lower bicarbonate fixation in the dredged $R$. nodastrella). In $H$. thielei, the contribution of DIC fixation to total biomass production on dissolved carbon was 16 to $17 \%$. In ambient water, the contribution of DIC fixation to total prokaryotic production was only $4 \%$ (Table 2 ). DIC incorporation represents a substantial fraction of the total dissolved $\mathrm{C}$ incorporation of sponge-microbe consortia in ultra-filtered seawater.

\section{DISCUSSION}

This study provides the first functional evidence of carbon incorporation from ambient dissolved organic and inorganic carbon by sponge-microbe consortia of deep water coral reefs. The association with prokaryotes apparently enables the sponges to exploit carbon sources that are generally believed to be unavailable to these organisms (Simpson 1984). Moreover, we found evidence for ammonia oxidation that may have fuelled the observed chemoautotrophic metabolism of the sponge-microbe consortia. We are aware that our data set is not exhaustive. Replicates are limited and variations between replicates were occasionally substantial, an inherent difficulty of collecting sufficient live sponge material for experiments from these deep water coral reefs. However, our results are consistent overall and contribute to a better understanding of the productivity of sponges on cold water coral reefs.

\section{Dissolved organic carbon incorporation in sponges}

We established leucine incorporation into proteins in the deep water coral mound sponges Higginsia thielei and Rossella nodastrella. Protein synthesis in sponges in the absence of particulate organic matter (ultrafiltered seawater) is most likely due to DOM assimilation. This implies that these sponges actually take up and incorporate bulk DOM from ambient water in a manner comparable to DOM removal by the sponge Theonella swinhoei (Yahel et al. 2003). H. thielei and $R$. nodastrella harbor sponge-associated prokaryotes that likely mediate DOM assimilation (Wilkinson \& Garrone 1979, Reiswig 1981). The choanocytes of the sponges may also consume DOM (taking into consideration their resemblance to DOM-consuming choanoflagellates, Sherr 1988, Tranvik et al. 1993). At nanomolar concentrations; however, leucine is primarily incorporated into proteins by prokaryotic rather than eukaryotic cells (Kirchman et al. 1985). Therefore, we 
assumed that during our $5 \mathrm{~h}$ incubations protein synthesis was performed predominantly by the spongeassociated prokaryotes. Most of the acquired DOM for synthesis of prokaryotic biomass probably came from the ambient water, but we cannot exclude input of exudates by sponge cells and by cell lysis during the incubations.

Leucine-based carbon production was 2 to $4 \mathrm{nmol} \mathrm{C}$ $\mathrm{cm}^{-3}$ sponge $\mathrm{d}^{-1}$, which is evidently higher than prokaryote carbon production in ambient bottom water ( 0.03 to $0.04 \mathrm{nmol} \mathrm{cm}^{-3} \mathrm{~d}^{-1}$ ). Whether DOM incorporation by associated prokaryotes is beneficial to the sponge cells is still unknown. Attributing production to the holobionts yields specific growth rates on DOC for Higginsia thielei and Rossella nodastrella of $<0.0005 \%$ $\mathrm{d}^{-1}$. This is considerably less than the specific growth rates of sponges reported in the literature (e.g. Thomassen \& Riisgård 1995). But the fact that it was incorporated suggests natural DOM may play a role in the maintenance of these cold water coral reef sponges. Surprisingly, the incorporation rates were comparable in the 2 sponge species, while the $\mathrm{C}$ content of $H$. thielei was significantly higher $(685 \mu \mathrm{mol} \mathrm{C}$

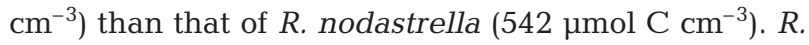
nodastrella, however, contained an amount of prokaryotic carbon $\left(0.21 \mu \mathrm{mol} \mathrm{C} \mathrm{cm}{ }^{-3}\right)$ comparable to that of $H$. thielei $\left(0.17 \mu \mathrm{mol} \mathrm{C} \mathrm{cm}^{-3}\right)$. Prokaryote abundance may be related to the dissolved organic carbon incorporation of the holobiont, as previously suggested by Reiswig (1971).

There are reasons to assume that leucine incorporation rates were underestimated. The bioavailable part of ambient bulk DOM is supposedly minute at these depths and may have been depleted during the $5 \mathrm{~h}$ incubation experiments. Moreover, the recovery of proteins may have been underestimated due to tissue hydrolysis with $\mathrm{NaOH}$ and subsequent acidification and precipitation of proteins on the filters.

\section{Bicarbonate fixation in sponges}

We present the first records of bicarbonate fixation by sponges in the dark ocean. In the dark ocean, bicarbonate fixation occurs only in prokaryotes (as far as we know). Bicarbonate fixation by the deep water sponges Higginsia thielei and Rossella nodastrella must therefore have been mediated by sponge-associated prokaryotes. Average rates measured fell in the range of carbon incorporation rates based on leucine incorporation; they were 0.7 and $4.5 \mathrm{nmol} \mathrm{cm}^{-3}$ sponge $\mathrm{d}^{-1}$ for $H$. thielei and $R$. nodastrella, respectively. These rates exceeded the bicarbonate fixation in the ambient water of coral mounds $\left(0.0043 \mathrm{nmol} \mathrm{cm}^{-3} \mathrm{~d}^{-1}\right)$ and deep Atlantic waters in the 200 to $1000 \mathrm{~m}$ depth range
(0.00011 to $0.00054 \mathrm{nmol} \mathrm{C} \mathrm{cm}^{-3} \mathrm{~d}^{-1}$, Herndl et al. 2005). Box-cored $R$. nodastrella had the highest rates. In dredged $R$. nodastrella, bicarbonate fixation may have been reduced by aerial exposure of specimens on the deck of the research vessel, but $\mathrm{CO}_{2}$-fixation rates still exceeded the control. Both sponges released ${ }^{14} \mathrm{C}$ DOC during incubation in all treatments, demonstrating definite bicarbonate fixation in organic matter by these organisms.

Bicarbonate fixation in Rossella nodastrella and Higginsia thielei suggests chemolithoautotrophy by ammonia or sulfur oxidizing associated prokaryotes. Nitrification is the most likely process for chemolithoautotrophy considering (1) enhancement of bicarbonate fixation after ammonium sulfate addition to live sponges without allylthiourea and (2) nitrite production by $H$. thielei and $R$. nodastrella. Moreover, nitrification and sponge-associated nitrifiers have been reported for several coral reef sponges in the past (e.g. Corredor et al. 1988, Diaz \& Ward 1997, Hentschel et al. 2002) and, more recently, for temperate sponges (Jiménez \& Ribes 2007). Our estimated nitrite productions by $H$. thielei and $R$. nodastrella were orders of magnitude lower than nitrification estimates of shallow water tropical sponges (Corredor et al. 1988, Diaz \& Ward 1997), but higher than ammonia oxidation rates reported for a deep-sea hydrothermal plume (Lam et al. 2004). Our nitrification rates indicate that ammonia is an energy source for chemolithoautotrophy in $H$. thielei and R. nodastrella.

Ammonium limitation of bicarbonate fixation by Higginsia thielei and Rossella nodastrella could not be established, despite the observed increases of bicarbonate fixation after ammonium sulfate addition. Sponges showed net excretion of ammonium during $24 \mathrm{~h}$ incubations regardless of $\left(\mathrm{NH}_{4}\right)_{2} \mathrm{SO}_{4}$ addition. Moreover, ambient ammonium concentrations near the reef bottom of coral mounds were quite high (140 to $298 \mathrm{nM}$ ), comparable to $\mathrm{NH}_{4}{ }^{+}$concentrations in a deep sea hydothermal plume, with ammonia oxidation rates of up to $91 \mathrm{nM} \mathrm{d}^{-1}$ (Lam et al. 2004). Therefore, it is unlikely that ammonia oxidation was limited by $\mathrm{NH}_{4}{ }^{+}$in $H$. thielei and $R$. nodastrella. This is surprising, because $\mathrm{NH}_{4}{ }^{+}$may be a profitable energy source for chemotrophs in such oligotrophic habitats. There may be other pathways of bicarbonate fixation (e.g. inorganic sulfur oxidation); it is more likely that nitrifying Bacteria are not the sole agents of nitrification in sponges. In our sponges, 11 to $18 \%$ of FISH positive prokaryotes were Archaea, with a dominance of Crenarchaea. There is recent evidence that certain Crenarchaeota are capable of oxidizing ammonia and fixing $\mathrm{CO}_{2}$ (Könneke et al. 2005). The sponge-associated Crenarchaeote Cenarchaeum symbiosum, which was isolated from the sponge Axinella mexicana (Preston et 
al. 1996), appears also to have the capacity to oxidize ammonia for energy and incorporate $\mathrm{CO}_{2}$ (Hallam et al. 2006). The ammonia monooxygenase which catalyzes ammonia oxidation may be different between Bacteria and Archaea (Francis et al. 2005, Hallam et al. 2006). Therefore allylthiourea, which has, as far as we know, only been related to ammonia oxidizing and methane oxidizing Bacteria (Bédard \& Knowles 1989), may not operate as an inhibitor of ammonia oxidation in Archaea. This implies that sponge-associated Archaea may have contributed to bicarbonate fixation.

We conclude that bicarbonate fixation occurs in Rossella nodastrella and Higginsia thielei and that we underestimated bicarbonate fixation by not accounting for the bicarbonate fixed in DOC. We argue that bicarbonate fixation may at least be partly due to spongeassociated nitrifying prokaryotes.

\section{Significance of dissolved carbon incorporation by cold water coral reef sponges}

Bicarbonate fixation rates in Higginsia thielei and Rossella nodastrella fell within the range of carbon production estimated with the leucine incorporation method, even without accounting for production of ${ }^{14} \mathrm{C}$-DOC by the sponge-microbe consortia. This suggests that bicarbonate fixation was quantitatively more important than leucine incorporation in the deep sea sponges. Strictly autotrophic prokaryotes may not be able to incorporate the leucine supplied into proteins. Therefore we added the DIC fixation rates to the leucine based carbon production rates to arrive at 'total dissolved $\mathrm{C}$ assimilation rates' of around $4.5 \mathrm{nmol} \mathrm{C}$ $\mathrm{cm}^{-3}$ sponge $\mathrm{d}^{-1}$ in $H$. thielei $\left(685 \mu \mathrm{mol} \mathrm{C} \mathrm{cm}^{-3}\right)$ and 4 to $9 \mathrm{nmol} \mathrm{C} \mathrm{cm}^{-3}$ sponge $\mathrm{d}^{-1}$ in $R$. nodastrella (542 umol C $\mathrm{cm}^{-3}$ ). If sponge-associated prokaryotes are responsible for this fixation rate, prokaryote production in sponges was 2 orders of magnitude higher than the production in ambient water. The specific growth rate in sponges was, however, 5 to 6 times lower than the planktonic prokaryote rate in bottom water; the disparity may be explained by our observation of sponge prokaryote densities 3 orders of magnitude higher than in ambient water. The sponges may keep prokaryote growth under control and antimicrobial substances may inhibit growth of associated prokaryotes (e.g. Hentschel et al. 2001).

Assuming that sponge-microbe consortia rely mainly on dissolved carbon for their carbon production (key carbon source DOM, Reiswig 1990), we may estimate sponge biomass doubling times of up to $287 \mathrm{yr}$ for Higginsia thielei and up to $150 \mathrm{yr}$ for box-cored Rossella nodastrella. These times seems unrealistically long, even at the slow growth rates recorded for such cold water sponges (Dayton 1979, Leys \& Lauzon 1998). Therefore, it is likely that these sponges filter particulate organic carbon in addition to consuming dissolved carbon.

Assuming a $2 \%$ assimilation efficiency of dissolved $\mathrm{C}$ by the sponge-microbe consortia (= growth yield of planktonic prokaryotes in the deep sea, Reinthaler et al. 2006), we arrive at a gross dissolved carbon

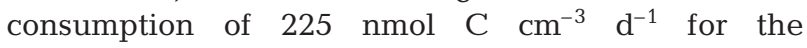
sponge-microbe consortium in Higginsia thielei and 200 to $350 \mathrm{nmol} \mathrm{C} \mathrm{cm}{ }^{-3} \mathrm{~d}^{-1}$ in Rossella nodastrella. To obtain a comparable amount (225 and 200 to $350 \mathrm{nmol}$ $\mathrm{C} \mathrm{cm}^{-3}$ sponge $\mathrm{d}^{-1}$, respectively) of particulate carbon in the form of planktonic prokaryotes, $H$. thielei would have to filter $0.008 \mathrm{~cm}^{3} \mathrm{~cm}^{-3}$ sponge $\mathrm{s}^{-1}$ and $R$. nodastrella 0.008 to $0.014 \mathrm{~cm}^{3} \mathrm{~cm}^{-3}$ sponge $\mathrm{s}^{-1}$ (based on the ambient prokaryote biomass, viz. $3.58 \times 10^{5} \mathrm{~cm}^{-3}$ and a $\mathrm{C}$ content of $10 \mathrm{fg} \mathrm{C} \mathrm{Cell}^{-1}$ ) at $100 \%$ retention efficiency. Such pumping rates fall within the reported ranges of 0.002 to $0.84 \mathrm{~cm}^{3} \mathrm{~cm}^{-3}$ sponge $\mathrm{s}^{-1}$ for pumping (Simpson 1984). The assumed retention efficiency is at the higher end of reported particle retention rates of 28 to $99 \%$ (e.g. Reiswig 1981, Pile 1997, Yahel et al. 2007). The efficiency with which POC is retained is orders of magnitude higher than for dissolved carbon; thus, despite its lower concentration $(0.3 \mu \mathrm{M}$ prokaryotic carbon), POC is as quantitatively abundant for sponges as dissolved carbon at the assumed pumping rate of $0.01 \mathrm{~cm}^{3} \mathrm{~cm}^{-3}$ sponge $\mathrm{s}^{-1}$. With an assimilation efficiency of $2 \%$ for dissolved carbon and $40 \%$ for POC, POC feeding (100\% retention, pumping rate of $0.01 \mathrm{~cm}^{3} \mathrm{~cm}^{-3}$ sponge $\mathrm{s}^{-1}$ ) yields 15 to 26 times more carbon for synthesis ( $>90 \%$ of the complete diet) than dissolved carbon. We argue that $H$. thielei and $R$. nodastrella use dissolved as well as particulate carbon, with POC as the most important food source. It remains to be seen whether the capacity to use dissolved carbon is crucial for the survival and maintenance of these sponges during periods of low particulate food concentrations in the deep sea.

\section{CONCLUSIONS}

In cold water coral reef systems in the dark ocean, the sponges Higginsia thielei and Rossella nodastrella assimilated dissolved carbon at ambient concentrations. Chemoautotrophy was found to be as quantitatively important as heterotrophy on DOC for these sponges. Energy for $\mathrm{CO}_{2}$ fixation by the sponges was partly derived from ammonia oxidation. The carbon incorporation of sponge-microbe consortia, along with their filter-feeding abilities, provide these sponges with a suite of nutritional capabilities in their oligotrophic, cold water coral reef habitat. 
Acknowledgements. We thank the captain and crew of the RV 'Pelagia' for their help on the research cruise to Rockall Bank. We are grateful for the logistic support of NIOZ technicians and NIOZ-MRF. R. van Soest is thanked for sponge species determinations and E. Meesters for statistical advice. J. van Ooijen, S. Gonzalez and S. Crayford are acknowledged for inorganic nutrient and organic matter analyses. This research was funded by grants from the Netherlands Organization for Scientific Research, NWO-ALW (BIOSYS, project 835.20.024 and 814.01.005).

\section{LITERATURE CITED}

Bédard C, Knowles R (1989) Physiology, biochemistry, and specific inhibitors of $\mathrm{CH}_{4}, \mathrm{NH}_{4}{ }^{+}$and $\mathrm{CO}$ oxidation by methanotrophs and nitrifiers. Microbiol Rev 53:68-84

Corredor JE, Wilkinson CR, Vincente VP, Morell JM, Otero O (1988) Nitrate release by Caribbean reef sponges. Limnol Oceanogr 33:114-120

Dayton PK (1979) Observations of growth, dispersal and population dynamics of some sponges in McMurdo Sound, Antarctica. In: Levi C, Boury-Esnault N (eds) Colloq Int Cent Nat Rech Sci 291:271-282

De Goeij JM, Van Duyl FC (2007) Coral cavities are sinks of dissolved organic matter. Limnol Oceanogr 52: 2608-2617

De Goeij JM, Van den Berg H, Van Oostveen MM, Epping EHG, Van Duyl FC (2008) Major bulk dissolved organic carbon (DOC) removal by encrusting coral reef cavity sponges. Mar Ecol Prog Ser 357:139-151

$>$ Diaz MC, Ward BB (1997) Sponge-mediated nitrification in tropical benthic communities. Mar Ecol Prog Ser 156: 97-107

Ducklow HW (2000) Bacterial production and biomass in the oceans. In: Kirchman DL (ed) Microbial ecology of the oceans. Wiley-Liss, New York p 85-120

> Duineveld GCA, Lavaleye MSS, Berghuis EM (2004) Particle flux and food supply to a seamount cold-water coral community (Galicia Bank, NW Spain). Mar Ecol Prog Ser 277: $13-23$

Francis CA, Roberts KJ, Beman JM, Santoro AE, Oakley BB (2005) Ubiquity and diversity of ammonia oxidizing archaea in water columns and sediments of the ocean. Proc Natl Acad Sci USA 102:14683-14688

Frederiksen R, Jensen A, Westerberg H (1992) The distribution of the scleractinian coral Lophelia pertusa around the Faroe islands and the relation to internal tidal mixing. Sarsia 77:157-171

Grasshoff K, Kremling K, Ehrhardt M (1999) Methods of seawater analysis. Wiley-VCH, Weinheim

> Hallam SJ, Mincer TJ, Schleper C, Preston CM, Roberts K, Richardson PM, DeLong EF (2006) Pathways of carbon assimilation and ammonia oxidation suggested by environmental genomic analyses of marine Crenarchaeota. PLoS Biol 4:520-536

> Hentschel U, Schmid MC, Wagner M, Fieseler L, Gernert C, Hacker J (2001) Isolation and phylogenetic analysis of bacteria with antimicrobial activities from the Mediterranean sponges Aplysina aerophoba and Aplysina cavernicola. FEMS Microbiol Ecol 35:305-312

Hentschel U, Hopke J, Horn M, Friedrich AB, Wagner M, Hacker J, Moore BS (2002) Molecular evidence for a uniform microbial community in sponges from different oceans. Appl Environ Microbiol 68:4431-4440

> Herndl GJ, Reinthaler T, Teira E, Van Aken H, Veth C, Pernthaler A, Pernthaler J (2005) Contribution of Archaea to total prokaryotic production in the deep Atlantic Ocean. Appl Environ Microbiol 71:2303-2309

Hopkinson CS Jr, Vallino JJ (2005) Efficient export of carbon to the deep ocean through dissolved organic matter. Nature 433:142-145

Hovland M, Thomsen E (1997) Cold-water corals-Are they hydrocarbon seep related? Mar Geol 137:159-164

Ingalls AE, Shah SR, Hansman RL, Aluwihare LI, Santos GM, Druffel ERM, Pearson A (2006) Quantifying archaeal community autotrophy in the mesopelagic ocean using natural radiocarbon. Proc Natl Acad Sci USA 103:6442-6447

Jensen A, Frederiksen R (1992) The fauna associated with the bank-forming deepwater coral Lophelia pertusa (Scleractinaria) on the Faroe shelf. Sarsia 77:53-69

Jiménez E, Ribes M (2007) Sponges as a source of dissolved inorganic nitrogen: nitrification mediated by temperate sponges. Limnol Oceanogr 52:948-958

Kirchman D, K'Nees E, Hodson R (1985) Leucine incorporation and its potential as a measure of protein synthesis by bacteria in natural aquatic systems. Appl Environ Microbiol 49:599-607

Kiriakoulakis K, Bett BJ, White M, Wolff GA (2004) Organic biogeochemistry of the Darwin Mounds, a deep-water coral ecosystem, of the NE Atlantic. Deep-Sea Res I 51: 1937-1954

Könneke M, Bernhard AE, De la Torre JR, Walker CB, Waterbury JB, Stahl DA (2005) Isolation of an autotrophic ammonia-oxidizing marine archeon. Nature 437:543-546

Lam P, Cowen JP, Jones RD (2004) Autotrophic ammonia oxidation in a deep-sea hydrothermal plume. FEMS Microbiol Ecol 47:191-206

Leys SP, Lauzon NRJ (1998) Hexactinellid sponge ecology: growth rates and seasonality in deep water sponges. J Exp Mar Biol Ecol 230:111-129

Masson DG, Bett BJ, Billett DSM, Jacobs CL, Wheeler AJ, Wynn RB (2003) The origin of deep-water coral-topped mounds in the northern Rockall Trough, Northeast Atlantic. Mar Geol 194:159-180

Müller WEG, Wiens M, Batel R, Steffen R, Schröder HC, Borojevic R, Custodio MR (1999) Establishment of primary cell culture from a sponge: primmorphs from Suberites domuncula. Mar Ecol Prog Ser 178:205-219

Pile AJ (1997) Finding Reiswig's missing carbon: quantification of sponge feeding using dual-beam cytometry. Proc 8th Int Coral Reef Symp 2:1403-1410

Pile AJ, Patterson MR, Witman JD (1996) In situ grazing on plankton $<10 \mu \mathrm{m}$ by the boreal sponge Mycale lingua. Mar Ecol Prog Ser 141:95-102

Porter KG, Feig YS (1980) The use of DAPI for identifying and counting aquatic microflora. Limnol Oceanogr 25:943-948

Preston CM, Wu KY, Miolinski TF, DeLong EF (1996) A psychrophilic crenarchaeon inhabits a marine sponge: Cenarchaeum symbiosum gen. nov., sp. nov. Proc Natl Acad Sci USA 93:6241-6246

Reinthaler T, Van Aken H, Veth C, Lebaron P and others (2006) Prokaryotic respiration and production in the mesoand bathypelagic realm of the eastern and western North Atlantic basin. Limnol Oceanogr 51:1262-1273

Reiswig HM (1971) In situ pumping activities of tropical Demospongiae. Mar Biol 9:38-50

Reiswig HM (1981) Partial carbon and energy budgets of the bacteriosponge Verongia fistularis (Porifera: Demospongiae) in Barbados. PSZN I: Mar Ecol 2:273-293

Reiswig HM (1990) In situ feeding in two shallow-water Hexactinellid sponges. In: Rützler K (ed) New perspectives in sponge biology. Smithsonian Institution Press, Washington, DC, p 504-510 
Reitner J, Hoffmann F (2003) Porifera-Zonierungen in Kaltwasser-Korallenriffen (Sula-Rücken, Norwegen). In: Gradstein SR, Willmann R, Zizka G (eds) Biodiversitätsforschung: die Entschlüsselung der Artenvielfalt in Raum und Zeit. Kleine Senckenberg-Reihe 45. Schweizerbart'sche Verlagsbuchhandlung, Stuttgart, p 75-87

Roberts JM, Wheeler AJ, Freiwald A (2006) Reefs of the deep: the biology and geology of cold-water coral ecosystems. Science 312:543-547

Rogers AD (1999) The biology of Lophelia pertusa (Linnaeus 1758) and other deep water reef-forming corals and impacts from human activities. Int Rev Hydrobiol 84: 315-406

Sherr EB (1988) Direct use of high molecular weight polysaccharide by heterotrophic flagellates. Nature 335: 348-351

Simon M, Azam F (1989) Protein content and protein synthesis rates of planktonic marine bacteria. Mar Ecol Prog Ser 51:201-213

Simpson TL (1984). The cell biology of sponges. SpringerVerlag, New York

Stoll MHC, Bakker K, Nobbe GH, Haese RR (2001) Continuous flow analysis of dissolved inorganic carbon content in seawater. Anal Chem 73:4111-4116

Taylor MW, Radax R, Steger D, Wagner M (2007) Spongeassociated microorganisms: evolution, ecology, and biotechnological potential. Microbiol Mol Biol Rev 71:295-347

Teira E, Reinthaler T, Pernthaler A, Pernthaler J, Herndl GJ (2004) Combining catalyzed reporter depositionfluorescence in situ hybridization and microautoradiography to detect substrate utilization by Bacteria and Archaea in the deep ocean. Appl Environ Microbiol 70: $4411-4414$

Thomassen S, Riisgård HU (1995) Growth and energetics of the sponge Halichondria panicea. Mar Ecol Prog Ser 128: 239-246

Tranvik LJ, Sherr EB, Sherr BF (1993) Uptake and utilization of 'colloidal DOM' by heterotrophic flagellates in seawater. Mar Ecol Prog Ser 92:301-309

Vacelet J, Donadey C (1977) Electron microscope study of the association between some sponges and bacteria. J Exp Mar Biol Ecol 30:301-314

Editorial responsibility: Pei-Yuan Qian,

Clearwater Bay, Hong Kong, SAR
Van Duyl FC, Duineveld GCA and scientific crew (2005) Biodiversity, ecosystem functioning and food web complexity of deep water coral reefs in the North East Atlantic (Rockall Bank and Porcupine Bank). BIOSYS-HERMES Cruise Report RV 'Pelagia' Cruise 64PE238. Royal Netherlands Institute for Sea Research, Texel, Netherlands

Van Soest RWM, Cleary D, De Kluijver MJ, Lavaleye MSS, Maier C, Van Duyl FC (2007a) Sponge diversity and community composition in Irish bathyal coral reefs. Contrib Zool 76:121-142

Van Soest RWM, Van Duyl FC, Maier C, Lavaleye MSS, Beglinger EJ, Tabachnick KR (2007b) Mass occurrence of the hexactinellid Rossella nodastrella Topsent in bathyal coral reefs of Rockall Bank, W of Ireland. In: Custódio MR, Lôbo-Hajdu G, Hajdu E, Muricy G (eds) Porifera research biodiversity, innovation and sustainability. Museu Nacional, Rio de Janeiro, p 645-652

Verardo DJ, Froelich PN, Macintyre A (1990) Determination of organic carbon and nitrogen in sediments using the Carlo Erba Na-1500 analyser. Deep-Sea Res A 37:157-165

Wilkinson CR (1978a) Microbial associations in sponges. I. Ecology, physiology and microbial populations of coral reefs. Mar Biol 49:161-167

Wilkinson CR (1978b) Microbial associations in sponges. II. Numerical analysis of sponge and water bacterial populations. Mar Biol 49:169-176

Wilkinson CR, Garrone R (1979) Nutrition of marine sponges. Involvement of symbiotic bacteria in the uptake of dissolved carbon. In: Tiffon Y, Smith DC (eds) Nutrition in the lower metazoa. Pergamon Press, Oxford, p 157-161

Wuchter C, Schouten S, Boschker HTS, Sinnighe Damsté JS (2003) Bicarbonate uptake by marine Crenarcheota. FEMS Microbiol Lett 219:203-207

Yahel G, Sharp JH, Marie D, Hase C, Genin A (2003) In situ feeding and element removal in the symbiont-bearing sponge Theonella swinhoei: bulk DOC is the major source for carbon. Limnol Oceanogr 48:141-149

Yahel G, Whitney F, Reiswig HM, Eerkes-Medrano DI, Leys SP (2007) In situ feeding and metabolism of glass sponges (Hexactinellida, Porifera) studied in a deep temperate fjord with a remotely operated submersible. Limnol Oceanogr 52:428-440

Submitted: December 6, 2006; Accepted: December 14, 2007 Proofs received from author(s): March 28, 2008 